\title{
The Intriguing Conundrum of a Nonconserved Multifunctional Protein of Citrus Tristeza Virus That Interacts with a Viral Long Non-Coding RNA
}

\author{
Sung-Hwan Kang 1, $+\ddagger$, Vicken Aknadibossian 1, , Laxmi Kharel ${ }^{2}$, Shachinthaka D. Dissanayaka Mudiyanselage ${ }^{2}$, \\ Ying Wang ${ }^{2} \mathbb{D}$ and Svetlana Y. Folimonova ${ }^{1, * \mathbb{D}}$ \\ 1 Plant Pathology Department, University of Florida, Gainesville, FL 32611, USA; \\ shk0015@auburn.edu (S.-H.K.); v.aknadibossian@ufl.edu (V.A.) \\ 2 Department of Biological Sciences, Mississippi State University, Mississippi State, MS 39762, USA; \\ 9laxsu9@gmail.com (L.K.); sdd292@msstate.edu (S.D.D.M.); wang@biology.msstate.edu (Y.W.) \\ * Correspondence: svetlana@ufl.edu \\ + Current address: Department of Entomology and Plant Pathology, Auburn University, \\ Auburn, AL 36849, USA. \\ $\ddagger \quad$ These authors contributed equally to this work.
}

\section{check for}

updates

Citation: Kang, S.-H.;

Aknadibossian, V.; Kharel, L.;

Mudiyanselage, S.D.D.; Wang, Y.;

Folimonova, S.Y. The Intriguing

Conundrum of a Nonconserved

Multifunctional Protein of Citrus Tristeza Virus That Interacts with a Viral Long Non-Coding RNA. Viruses 2021, 13, 2129. https://doi.org/ $10.3390 /$ v13112129

Academic Editor: Feng Qu

Received: 24 September 2021

Accepted: 19 October 2021

Published: 22 October 2021

Publisher's Note: MDPI stays neutral with regard to jurisdictional claims in published maps and institutional affiliations.

Copyright: (c) 2021 by the authors. Licensee MDPI, Basel, Switzerland. This article is an open access article distributed under the terms and conditions of the Creative Commons Attribution (CC BY) license (https:// creativecommons.org/licenses/by/ $4.0 /)$.
Abstract: Citrus tristeza virus (CTV), the largest non-segmented plant RNA virus, has several peculiar features, among which is the production of a $5^{\prime}$-terminal long non-coding RNA (lncRNA) termed low-molecular-weight tristeza 1 (LMT1). In this study, we found that p33, a unique viral protein that performs multiple functions in the virus infection cycle, specifically binds LMT1, both in vivo and in vitro. These results were obtained through the expression of p33 under the context of the wild type virus infection or along with a mutant CTV variant that does not produce LMT1 as well as via ectopic co-expression of p33 with LMT1 in Nicotiana benthamiana leaves followed by RNA immunoprecipitation and rapid amplification of cDNA ends assays. Further experiments in which a recombinant $\mathrm{p} 33$ protein and an in vitro transcribed full-length LMT1 RNA or its truncated fragments were subjected to an electrophoretic mobility shift assay demonstrated that p33 binds to at least two distinct regions within LMT1. To the best of our knowledge, this is the first report of a plant virus protein binding to a lncRNA produced by the same virus. The biological significance of the interaction between these two viral factors is discussed.

Keywords: RNA virus; closterovirus; citrus tristeza virus; long non-coding RNA; plant virus; RNAbinding protein; RNA immunoprecipitation assay; electrophoretic mobility shift assay

\section{Introduction}

Citrus tristeza virus (CTV), a member of the family Closteroviridae, is the largest nonsegmented plant RNA virus that is responsible for two of the most destructive viral diseases of citrus: quick decline and stem pitting [1-8]. The $19.3 \mathrm{~kb}$ single-stranded positive-sense RNA genome of CTV is encapsidated by two coat proteins, the major and minor coat proteins (CP and CPm, respectively), resulting in a long flexuous virion (2000 $\mathrm{nm}$ by 10-12 nm). Apart from the genomic RNA (gRNA) and its negative-sense complimentary copy, CTV produces more than 30 sub-genomic RNAs (sgRNAs) and a number of different defective RNAs upon replication in the infected cells [9-12]. Among those are the two positive-sense $5^{\prime}$-coterminal non-coding sgRNAs termed low-molecular-weight tristeza 1 (LMT1) and LMT2 [11,13]. LMT2 ( 650 nucleotides (nts)) has no known function and is thought to be processed during virion assembly [14]. On the other hand, LMT1 ( 750 nts) is generated through replication by initiation at the $3^{\prime}$ end of the negative strand copy of gRNA and termination at the respective controller element $[11,15]$. Recently, we showed that LMT1 plays a role in counter-acting the host defense responses and is required for citrus infection [16]. 
The CTV genome encodes 12 open reading frames (ORFs; Figure 1) $[9,17]$. ORFs 1a and $1 \mathrm{~b}$ are translated directly from gRNA and code for polyproteins that function in virus replication $[3,9,18]$. The remaining ten ORFs are expressed from $3^{\prime}$-coterminal sgRNAs. The CP, CPm, p65, and p61 proteins are required for virion assembly and, along with p6, for virus movement $[3,19,20]$. CP, p20, and p23 act as viral suppressors of host RNA silencing (VSRs) [21]. CTV also produces three unique proteins-p13, p18, and p33-which extend the virus host range [20,22].

A

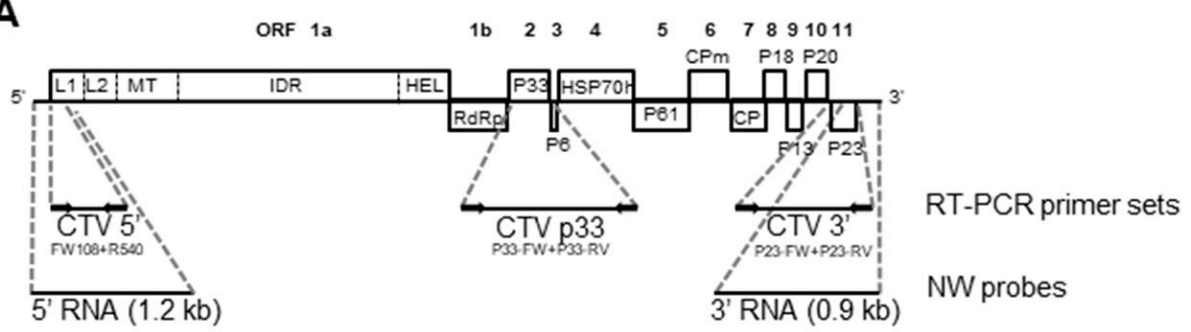

B
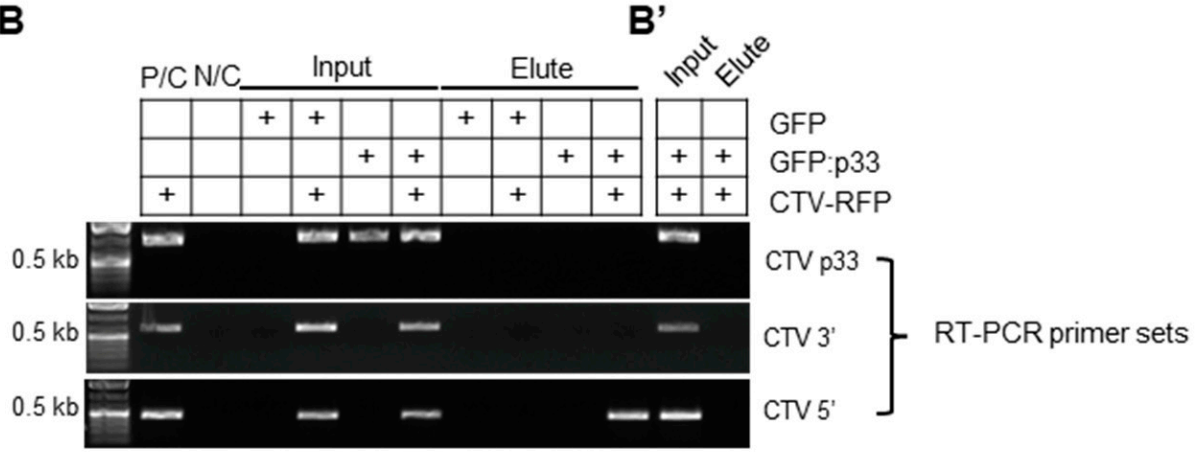

C

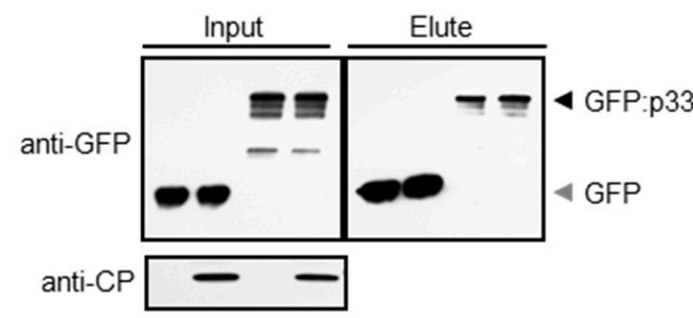

D

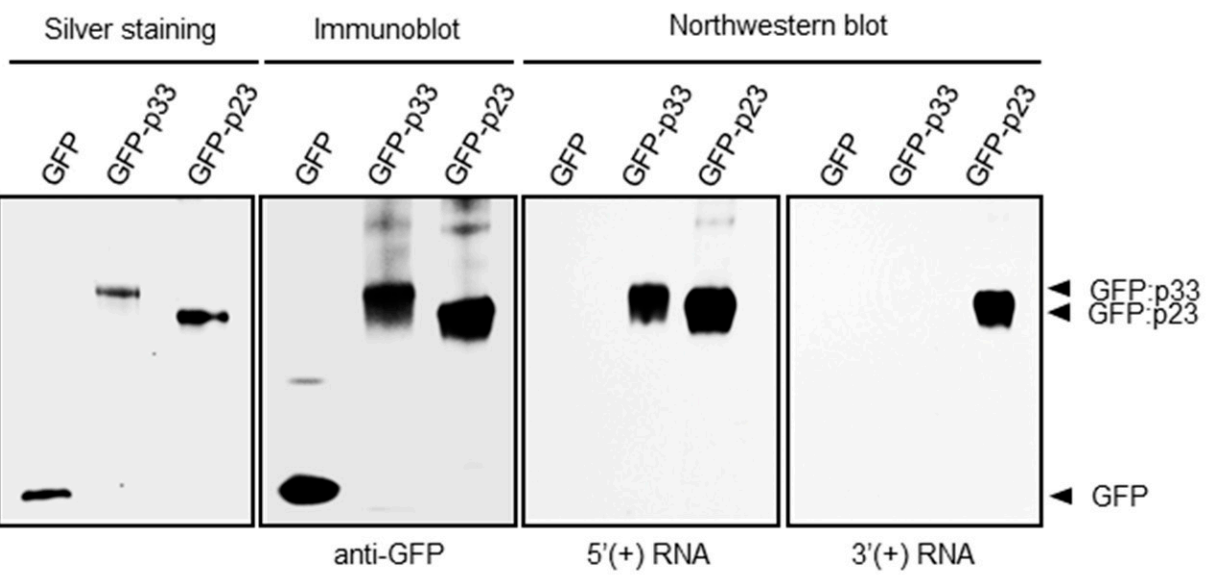

Figure 1. RNA-binding property of the p33 protein. (A) Schematic representation of the CTV genome and the regions targeted for the amplification and probe hybridization of RNA bound to the protein trapped via anti-GFP antibody-conjugated agarose beads in the RIP assay. The boxes represent ORFs and their translated products. L1 and L2, papain-like leader proteases; MT, methyltransferase; IDR, 
large interdomain region; HEL, helicase; RdRp, RNA-dependent RNA polymerase; CPm, minor coat protein; HSP70h, heat shock protein 70 homolog; $\mathrm{CP}$, coat protein. Sequences of primers can be found in Supplementary Table S1. (B) RT-PCR analysis of the RNA extracted at two steps ("Input" and "Elute") of the RIP assay. Input:- the supernatant of the leaf homogenate in the lysis buffer after centrifugation at $3000 \times g$; Elute:-beads left at the final step of RIP after repeated washes. The table above the agarose gel image shows the components expressed in leaves of $N$. benthamiana in the RIP assay treatments. $\mathrm{P} / \mathrm{C}$, positive control in which leaves were infiltrated with pCTV:RFP; $\mathrm{N} / \mathrm{C}$, negative control in which leaves were infiltrated with the empty vector. The agarose gel images show products amplified by RT-PCR using the set of primers targeting the p33 ORF, the $3^{\prime}$ terminus, or the $5^{\prime}$ terminus of the CTV genome (top, middle, and bottom, respectively) as shown in (A). (B') RT-PCR analysis of the RNA extracted at two steps ("Input" and "Elute") of the RIP assay as described in (B), except that the RT step was performed using forward primers to detect negative-stranded RNA by subsequent PCR. (C) Immunoblot analysis of the total protein extracts from the supernatant of the homogenate and the beads at the final step of RIP assay ("Input" and "Elute", respectively; see Section 2). Input represented all the components expressed in N. benthamiana using agroinfiltration. Elute contained trapped GFP-tagged p33 or GFP. (D) GFP and GFP-tagged CTV proteins (GFP:p33 and GFP:p23) expressed individually in N. benthamiana were purified using GFP-Trap and analyzed by SDS-PAGE. "Silver staining" shows the proteins separated by SDSPAGE, "Immunoblot" shows detection of GFP, GFP:p33 and GFP:p23 using anti-GFP antibody. "Northwestern blot": proteins transferred from the gel onto the nitrocellulose membrane were renatured and subsequently incubated with in vitro-transcribed DIG-labelled RNAs $\left(5^{\prime}\right.$ and $3^{\prime}$ probes targeting the regions indicated in (A)). Both RNA probes $\left(5^{\prime}(+)\right.$ and $3^{\prime}(+)$ RNAs) were bound to GFP:p23 known as non-specific RNA binding protein, however, only $5^{\prime}(+)$ RNA probe was bound to GFP:p33.

The nonconserved p33 protein was shown to perform multiple functions in the CTV infection cycle. It plays a crucial role in virus superinfection exclusion by mediating the ability of a variant of CTV to exclude superinfection by a closely related virus variant [23,24]. Recently, it was also demonstrated that p33 is a viral effector that modulates the host immune response and, thus, influences the virus's pathogenicity [25]. Furthermore, p33 has been implicated in virus translocation throughout the host plants. Although p33 is not essential for systemic infection in a number of citrus hosts, the protein influences the efficiency of the virus systemic spread [22,26,27]. Moreover, it is indispensable for CTV infection of certain other hosts (e.g., sour orange and lemon) [22]. The protein itself was shown to possess multiple characteristics of viral movement proteins (MPs). In particular, p33 has the ability to form extracellular tubules, which appear to originate from the deposits of p33 at the plasmodesmata [26,28]. The MPs of other tubule-forming viruses such as like Cowpea mosaic virus and Grapevine fanleaf virus have been reported to interact with their respective CPs, and this interaction was required for virion transport [29]. Similarly, the CTV p33 also interacts with the viral CP [30]. All these observations led to the suggestion that p33 could play a role of a noncanonical MP, which is needed for virus translocation in the selective hosts.

To date, at least 36 plant virus MPs were reported to bind nucleic acids, all in a sequence-non-specific manner [31]. For instance, the ability of Red clover necrotic mosaic virus (RCNMV) and Prunus necrotic ringspot virus MPs to bind RNA was required for cell-to-cell movement $[32,33]$, while that of a Poa semilatent virus MP, TGBp1, was needed for virus systemic movement [34]. Ultimately, the RNA-binding property of viral MPs seems to play an integral part in virus movement. In this work, we show that the p33 protein of CTV is an RNA-binding protein. However, unlike many other MPs of plant viruses, which bind RNA in a sequence-non-specific manner, p33 binds a particular RNA species produced during virus replication in the infected cells-a viral long non-coding RNA (lncRNA) LMT1. The p33 protein interacts with LMT1 both in vivo and in vitro, and the interaction is in a cooperative manner, suggesting multiple binding sites in the LMT1 sequence. 


\section{Materials and Methods}

\subsection{In-Silico Sequence Analysis}

The prediction of RNA binding motif was performed with Genesilico Fold Prediction Metaserver (https: / / www.genesilico.pl/meta2/, accessed on 6 October 2011) and InterPro (http:/ / www.ebi.ac.uk/interpro/, accessed on 6 October 2011) using the p33 amino acid (aa) sequence of the T36 isolate of CTV (EU937521).

\subsection{Agroinfiltration into Nicotiana Benthamiana}

Agroinfiltration of constructs was conducted as previously described [26]. Briefly, plasmids were introduced by heat shock into Agrobacterium tumefaciens EHA105, and the resulting transformants were selected on Luria-Bertani agar plates containing two antibiotics ( $50 \mu \mathrm{g} / \mathrm{mL}$ rifampicin and $25 \mu \mathrm{g} / \mathrm{mL}$ kanamycin). Cells collected from an overnight culture of a selected single colony were gently resuspended in a buffer containing $10 \mathrm{mM}$ 2-(N-morpholino) ethane sulfonic acid (MES, pH 5.85), $10 \mathrm{mM} \mathrm{MgCl}_{2}$ and $150 \mathrm{mM}$ acetosyringone at O.D. ${ }_{600 \mathrm{~nm}}=1.0$. After a $3 \mathrm{~h}$ incubation at room temperature without shaking, the suspension was infiltrated into six-week-old $N$. benthamiana plants using a needleless syringe.

\subsection{RNA Immunoprecipitation Assay}

Total protein was extracted from the infiltrated leaves of $N$. benthamiana by grinding in a lysis buffer ( $50 \mathrm{mM}$ Tris- $\mathrm{HCl}, 1 \mathrm{mM}$ EDTA, $150 \mathrm{mM} \mathrm{NaCl}, 5 \%$ glycerol) containing protease inhibitor cocktail (AEBSF, Bestatin, E-64, Leupeptin, Pepstatin A, and 1,10-Phenanthroline; MilliporeSigma, Burlington, MA, USA). The homogenate was incubated on ice for $1 \mathrm{~h}$ with gentle shaking on the rocker and then clarified by centrifugation at $3000 \times g$ for $10 \mathrm{~min}$ at $4{ }^{\circ} \mathrm{C}$. The supernatant $(600 \mu \mathrm{L})$ was immunoprecipitated using GFP-Trap ${ }^{\circledR}$ or RFP-Trap ${ }^{\circledR}$ (ChromoTek GmbH, Planegg-Martinsried, Germany)—anti-green fluorescent protein (GFP) or anti-red fluorescent protein (RFP) antibody-conjugated agarose beads $(50 \mu \mathrm{L})$-by incubating for $2 \mathrm{~h}$ on ice with gentle shaking. The supernatant described at this step was also used as an 'Input' sample for reverse transcription-PCR (RT-PCR) or immunoblot analysis. The binding reaction was washed three times as per the manufacturer's instruction by centrifugation at $3000 \times g$ for $2 \mathrm{~min}$ at $4^{\circ} \mathrm{C}$. The pellet of the agarose beads collected at this step was used as 'Elute' for further analysis. For the immunoblot analysis, total protein was extracted as described below. For RT-PCR analysis, total RNA was extracted using the TRIzol ${ }^{\mathrm{TM}}$ reagent (Invitrogen, Waltham, MA, USA) according to the manufacturer's procedure. RNA extracts were resuspended in $50 \mu \mathrm{L}$ of RNase-free water.

\subsection{RT-PCR Assay}

Total RNA extracts described above were measured using NanoDrop UV-Vis Spectrophotometer (Thermo-Fisher Scientific, Waltham, MA, USA), diluted with RNase-free water to adjust concentration to $1 \mathrm{ng} / \mu \mathrm{L}$, and used as a template for an RT-PCR reaction. RT-PCR was performed using SuperScript ${ }^{\text {TM }}$ III One-Step RT-PCR System with Platinum Taq DNA Polymerase (Invitrogen, Waltham, MA, USA) in $20 \mu \mathrm{L}$ volume $(10 \mu \mathrm{L} 2 \mathrm{X}$ reaction buffer, $1 \mu \mathrm{L}$ template RNA, $0.5 \mu \mathrm{L}$ forward primer of $20 \mu \mathrm{M}, 0.5 \mu \mathrm{L}$ reverse primer of $20 \mu \mathrm{M}, 1 \mu \mathrm{L}$ enzyme mix, and nano-pure water up to $20 \mu \mathrm{L}$ ). Complementary DNA (cDNA) synthesis was followed immediately by PCR amplification according to the manufacturer's procedure with 30 cycles. Reaction products were analyzed by electrophoresis in 1\% agarose gels containing ethidium bromide at $200 \mathrm{ng} / \mathrm{mL}$.

\subsection{Immunoblot Analysis}

All fractions were mixed with the equal volume of the $2 \mathrm{X}$ sample loading buffer $(125 \mathrm{mM}$ Tris- $\mathrm{HCl}, 4 \%(w / v)$ SDS, 20\% $(v / v)$ glycerol, and $0.01 \%(w / v)$ bromophenol blue) with dithiothreitol and boiled for $10 \mathrm{~min}$. Mixtures were briefly centrifuged prior to loading, electrophoresed through 10\% SDS-polyacrylamide gels, and electro-transferred to a polyvinylidene difluoride (PVDF) membrane. The membrane was blocked with $1 \mathrm{X}$ 
TBS-T (137 mM NaCl, $27 \mathrm{mM} \mathrm{KCl}, 250 \mathrm{mM}$ Tris-HCl, and 0.1\% Tween-20) containing $5 \%$ $(w / v)$ skim milk for an hour at room temperature prior to incubating with an anti-GFP, anti-RFP (dilution: 1:1000; Santa Cruz Biotechnology, Dallas, TX, USA) or anti-CP antibody (CTV-908 [35]; dilution: 1:500) with 1X TBS-T for another hour. Anti-rabbit IgG conjugated to horseradish peroxidase was used as a secondary antibody (dilution: 1:20,000; Santa Cruz Biotechnology, Dallas, TX, USA), and the signal was visualized on chemiluminescence film (X-OMAT LS; Carestream Health Rochester, NY, USA) in a dark room (Carestream Kodak, Sigma-Aldrich, St. Louis, MO, USA).

\subsection{Determination of the $5^{\prime}$ and $3^{\prime}$ Ends of RNA by Rapid Amplification of cDNA Ends (RACE)}

The RNA isolated from the agarose beads at the "Elute" step of the RNA immunoprecipitation (RIP) assay was used for the amplification and the RACE assays (SMARTer RACE kit; Clontech, Takara Bio Inc., Kusatsu, Japan) to determine the $5^{\prime}$ and $3^{\prime}$ ends of co-immunoprecipitated RNA. To determine the $5^{\prime}$ end, a random primer and manufacturersupplied adapter oligos were used for the first-strand cDNA synthesis. The $5^{\prime}$ RACE product was amplified using the forward primer supplied by the manufacturer and a CTVspecific reverse primer (GSP1). To determine the $3^{\prime}$ end of the RNA, the isolated RNA was polyadenylated using Escherichia coli poly (A) polymerase (Applied Biosystems, Waltham, MA, USA). The first strand synthesis and $3^{\prime}$ RACE was performed as instructed (SMARTer RACE kit; Clontech, Takara Bio Inc., Kusatsu, Japan) with a manufacturer-supplied reverse primer and a CTV-specific forward primer (GSP2). Both 5' and $3^{\prime}$ RACE products were cloned into the manufacturer-supplied vector and selected clones (10 for $5^{\prime}$ RACE and 100 for $3^{\prime}$ RACE) were sequenced (Psomagen, Rockville, MD, USA).

\subsection{Northwestern Blot Analysis}

Protein samples (approximately, $2 \mu \mathrm{g}$ ) were separated by electrophoresis through $10 \%$ SDS-PAGE and transferred onto a nitrocellulose membrane using semi-dry Trans-Blot apparatus (Bio-Rad Laboratories, Hercules, CA, USA). The membrane was incubated at room temperature in the $\mathrm{RN}$ (renaturation) buffer (10 mM Tris- $\mathrm{HCl}$ ( $\mathrm{pH}$ 7.5), $1 \mathrm{mM}$ EDTA, $50 \mathrm{mM}$ $\mathrm{NaCl}, 0.1 \%$ Triton X-100 and $1 \mathrm{X}$ Denhardt's reagent [36]) for $20 \mathrm{~min}$. The incubation was repeated three times. Then, the membrane was incubated with a digoxigenin (DIG)-labeled riboprobe specific to the positive-strand RNA corresponding to the $5^{\prime}$ or $3^{\prime}$ end of the CTV genome generated as described in Satyanarayana et al. [37], which was generated using a DIG-RNA labeling kit as per the manufacturer's instruction (Roche, Basel, Switzerland) in the RN buffer for one hour with slight agitation. The membrane was cross-linked by UV (auto-crosslink, Stratagene, San Diego, CA, USA). The membrane was washed three times for 20 min each with the RN buffer without Triton X-100 and Denhardt's reagent prior to the blocking in $1 \mathrm{X}$ maleate buffer. The membrane was treated with an anti-DIG antibody (anti-DIG-AP, Fab fragments, Roche, Basel, Switzerland) and detection was carried out with the alkaline phosphatase chemiluminescent substrate (CSPD; Roche, Basel, Switzerland) as described in the manufacturer's instructions (Roche, Basel, Switzerland).

\subsection{Protein Expression and Purification}

The p33 or the transmembrane domain (TMD) lacking p33 (p33 3 TMD) coding sequences were amplified using P33-FW and either P33-RV or P33 $\Delta$ TMD-RV (Supplementary Table S1) and were ligated into the glutathione S-transferase (GST) fusion protein expression vector pGEX-4T-1 (Cytiva, Marlborough, MA, USA) between EcoR I and Not I restriction enzyme recognition sites. The constructs were transformed into Rosetta strain (DE3) (MilliporeSigma, Burlington, MA, USA) competent cells. Protein expression induction was performed at $\mathrm{OD}_{600} \mathrm{~nm} 0.5-0.7$ with $0.4 \mathrm{mM}$ IPTG, and the cultures were then incubated at $20^{\circ} \mathrm{C}$ for overnight. Pellets were resuspended in 1X PBS buffer $(137 \mathrm{mM} \mathrm{NaCl}, 2.7 \mathrm{mM} \mathrm{KCl}$, $10 \mathrm{mM} \mathrm{Na}_{2} \mathrm{HPO}_{4}$, and $1.8 \mathrm{mM} \mathrm{KH}_{2} \mathrm{PO}_{4}$ ) supplemented with $20 \mathrm{mM}$ PMSF and sonicated to lyse the cells. The homogeneous cell lysate was centrifuged at $10,000 \times \mathrm{g}$ for $30 \mathrm{~min}$ at $4{ }^{\circ} \mathrm{C}$. The supernatant was collected and incubated for $1 \mathrm{~h}$ with $2 \mathrm{~mL}$ of $50 \%$ slurry of Glutathione 
Resin (GenScript, Piscataway, NJ, USA) before loading onto an empty EconoPac gravityflow column (Bio-Rad Laboratories, Hercules, CA, USA). The resin was then washed with $10 \mathrm{~mL} 1 \mathrm{X}$ BS followed by elution with $10 \mathrm{~mL}$ elution buffer $(50 \mathrm{mM}$ Tris- $\mathrm{HCl}$ at $\mathrm{pH} 8.0$ and $10 \mathrm{mM}$ reduced glutathione). The elutes were concentrated using an Amicon protein concentrator (MilliporeSigma, Burlington, MA, USA). Proteins were then separated by $8 \%$ SDS-PAGE electrophoresis followed by Coomassie blue staining and destaining to estimate concentration using a BSA standard as reference. Purified GST:p33 and GST elutes were run on $12 \%$ Mini-PROTEAN ${ }^{\circledR}$ TGX ${ }^{\mathrm{TM}}$ Precast Gels (Bio-Rad Laboratories, Hercules, CA, USA) and electro-transferred to PVDF membrane. Western blot was carried out with $0.5 \mu \mathrm{g} / \mathrm{mL}$ anti-GST tag rabbit anti-tag polyclonal primary antibody (Invitrogen, Waltham, MA, USA) and 1:20,000 goat anti-rabbit IgG (H + L) (HRP) secondary antibody (Abcam, Cambridge, UK) after blocking with 5\% non-fat milk in TBST. The PVDF membrane was treated with Clarity ${ }^{\mathrm{TM}}$ Western ECL Substrate (Bio-Rad Laboratories, Hercules, CA, USA) and visualized on Bio-Rad ChemiDoc ${ }^{\mathrm{TM}} \mathrm{XRS}+$ system with Image Lab ${ }^{\mathrm{TM}}$ software.

\subsection{Construction of Clones Encoding LMT1 and LMT1 Truncations for In Vitro Transcription}

A series of LMT1 clones was constructed. A fragment encompassing an extended full-length LMT1 (nt positions 1 to 780 in the CTV genome) and its truncated versions encompassing nt positions 201-400, 401-600, and 601-780 (fragments A, B, and C, respectively) were amplified by PCR using set of primers provided in Supplementary Table S1 (primer names begin with LMT). The amplified products were directly cloned into pGEM ${ }^{\circledR}$ T Easy plasmid (Promega, Madison, WI, USA) and sequenced using a pair of M13 primers listed in Supplementary Table S1 (Psomagen, Rockville, MD, USA) to verify the orientation of the insertions. For in vitro transcription, the plasmids harboring fragments $\mathrm{A}$ and B were linearized by Nde I (NEB, Ipswich, MA, USA) prior to transcription using T7 MEGAscript ${ }^{\mathrm{TM}}$ kit (Thermo-Fisher Scientific, Waltham, MA, USA). Plasmids harboring the full-length LMT1 and fragment $C$ were linearized by Nco I (NEB, Ipswich, MA, USA) before transcription using the SP6 MEGAScript ${ }^{\mathrm{TM}}$ Kit (Thermo-Fisher Scientific, Waltham, MA, USA).

\subsection{Electrophoretic Mobility Shift Assay (EMSA)}

The indicated amounts of purified GST:p33 TTMD or GST were incubated with $1 \mu \mathrm{M}$ of an RNA transcript in $10 \mu \mathrm{L}$ binding buffer $(10 \mathrm{mM}$ HEPES-NaOH pH $8.0,50 \mathrm{mM} \mathrm{KCl}$, $100 \mathrm{mM}$ EDTA, and $5 \%$ glycerol) for $20 \mathrm{~min}$ at $28{ }^{\circ} \mathrm{C}$ with gentle shaking. Subsequently, the incubated mixture was electrophoresed in $6 \%$ non-denaturing PAGE using $1 \mathrm{X}$ TAE buffer and transferred onto Hybond ${ }^{\mathrm{TM}}-\mathrm{XL}$ nylon membrane (Amersham Biosciences, Little Chalfont, United Kingdom) via a semi-dry transfer cassette (Bio-Rad Laboratories, Hercules, CA, USA) and was immobilized by a UV-crosslinker (UVP, Upland, CA, USA). The crosslinked membrane was blocked with Denhardt's solution (VWR, Radnor, PA, USA) for $30 \mathrm{~min}$ at $60^{\circ} \mathrm{C}$ before adding a DIG-labeled probe. After overnight hybridization, the location of RNA transcripts was detected using DIG-Northern-Detection-system (Roche, Basel, Switzerland) per the manufacturer's instructions. The Signals were captured by a ChemiDoc $^{\mathrm{TM}}$ (Bio-Rad Laboratories, Hercules, CA, USA). The Hill equation was plotted using the default function in Prism version 8 (GraphPad, San Diego, CA, USA).

\section{Results}

\subsection{The p33 Protein Is A Sequence-Specific RNA-Binding Protein}

In-silico analysis of the aa sequence of the p33 protein from the T36 isolate of CTV predicted a canonical arginine-rich RNA-binding motif (ARM) in the N-terminal region of the protein (Supplementary Figure S1; see Section 2), which implied the ability of p33 to bind RNA molecules via a well-conserved ARM (reviewed in [38]). To examine whether p33 binds viral RNA produced during CTV infection, we first used a RIP approach. The p33 protein tagged with the GFP was co-expressed with CTV in N. benthamiana plants through infiltration with an A. tumefaciens culture transformed with a binary vector carrying a 
fusion of the p33 ORF with that of GFP (pGFP:p33; [26]) positioned under the Cauliflower mosaic virus $35 \mathrm{~S}$ promoter along with a culture transformed with a vector carrying a cDNA clone of CTV tagged with an RFP gene (pCTV-RFP; [35]). At five days post infiltration (dpi), expression of GFP:p33 and CTV-RFP in the infiltrated leaves was confirmed by observation of GFP and RFP fluorescence, respectively (data not shown). Tissue extracts obtained from the infiltrated leaves were subjected to RIP using anti-GFP antibody-linked beads (GFP-Trap ${ }^{\circledR}$ ). To analyze the RNA bound to the GFP-tagged p33 protein, total RNA extracted from the beads at the final "Elute" step (see Section 2) was used as a template for RT-PCR with primer sets corresponding to three different regions of the CTV genome (Figure 1A). All primer sets successfully amplified the corresponding target regions from a total RNA extract of the leaves infiltrated solely with pCTV-RFP, which was used as a positive control for RT-PCR, as well as from the extracts of leaves co-expressing CTV-RFP and GFP:p33 that were obtained prior to the RIP procedure (Figure 1B; P/C and "Input", respectively). No amplification was detected from the total RNA extract from the leaves of the control plants infiltrated with an empty binary vector (Figure 1B; N/C). In contrast, RT-PCR using post-RIP GFP-p33-bound RNA obtained via co-immunoprecipitation of extracts from GFP:p33- and CTV-RFP-bearing samples resulted in the amplification of only the fragment corresponding to the $5^{\prime}$-proximal region of the CTV genome (Figure 1B; "Elute"). No amplification of the other two fragments corresponding to the central or the $3^{\prime}$-terminal genomic regions was detected. The RIP-subjected samples from the control plants expressing GFP and CTV-RFP did not yield any amplification, indicating that there was no binding of the CTV RNA to GFP. Presence of the protein components such as GFP:p33, GFP, and the viral CP in the respective fractions was verified by immunoblotting using a GFP-specific antibody for GFP and GFP:p33 and a CTV CP-specific antibody for CTV-RFP (Figure 1C).

The results of the above experiment suggested that p33 could bind a specific RNA, which sequence corresponds to that of the $5^{\prime}$ region of the virus genome. As CTV generates both negative- and positive-stranded RNAs during replication $[8,10]$, the polarity of the CTV RNA bound to GFP:p33 needed to be examined (Figure 1B'). Accordingly, we attempted to synthesize a cDNA from an RT reaction using the primers intended to anneal only to the negative-stranded copy of CTV RNA at positions located at the $3^{\prime}$, central, and $5^{\prime}$ regions, which was followed by PCR (Figure 1A, $\mathrm{B}^{\prime}$ ). As a result, no amplification of the fragments corresponding to any of the three regions was detected when the GFP:p33-bound RNA was used as the template, suggesting the absence of negative-stranded CTV RNAs.

To validate the results obtained by RIP and further characterize RNA binding properties of p33, we employed a different experimental technique-the northwestern blot analysis-and included another protein of CTV, p23, which is known as a non-sequencespecific RNA binding protein, as a control [39]. The GFP-tagged p33 and p23 proteins $([26,30]$, respectively) along with free GFP were individually expressed in the $N$. benthamiana leaves as described above and purified using GFP-Trap ${ }^{\circledR}$. The purified proteins were verified via SDS-PAGE followed by silver staining and immunoblotting using the GFP-specific antibody. The northwestern blot analysis using DIG-labelled RNA probes comprising the $5^{\prime}$ or $3^{\prime}$-terminal $\sim 1 \mathrm{~kb}$-region of the viral gRNA (Figure $1 \mathrm{~A}$ ) showed that both $5^{\prime}$ and $3^{\prime}$ probes were bound by the p23 protein, which was in the agreement with the previous finding that this protein of CTV binds RNA in a non-sequence-specific manner (Figure 1D). On the other hand, the p33 protein was found to bind only the $5^{\prime}$-terminal RNA probe that comprised the $5^{\prime}$-terminal 1.2-kb of gRNA but not the probe containing the $3^{\prime}$-terminal $0.9-\mathrm{kb}$ region of CTV gRNA. No binding between free GFP and either probe was detected. The obtained results indicated that the p33 protein is an RNA-binding protein and suggested that $\mathrm{p} 33$ could bind a specific RNA molecule(s) produced during virus infection.

\section{2. p33 Binds A Single sgRNA Species Produced from the $5^{\prime}$ End of the CTV Genome}

Upon replication, CTV produces more than 30 species of sgRNA molecules, including a set of different $5^{\prime}$ co-terminal sgRNAs [8]. Based on the results of our experiments 
discussed above, we speculated that p33 binds one of the latter RNAs. In order to identify which RNA was bound to p33, we first attempted to determine its size by performing RT-PCR using a forward primer corresponding to the $5^{\prime}$-terminal region of the CTV genome (FW108) and a series of reverse complementary primers annealing to variable positions within the first $2050 \mathrm{nts}$ in the $5^{\prime}$ genomic region (Figure 2A). The analysis was done in two steps: four different reverse primers binding at positions corresponding to nts 540 , 1050, 1550, and 2050 in the CTV genome (R540, R1050, R1550, and R2050, respectively; see Supplementary Table S1) were used in the initial step, while additional reverse primers (see below) were used in the second step to narrow down the size of the RNA molecule bound to p33. All primer sets successfully amplified the target regions from the positive control—a total RNA extract from leaves infiltrated with pCTV-RFP—and from the "input" samples bearing CTV-RFP and GFP:p33, confirming that the designed primer sets can efficiently detect the respective sequences in the CTV genome (Figure 2B,C). In contrast, the initial assessment using post-RIP GFP:p33-bound RNA demonstrated that among the four reverse primers only R540 yielded the amplification of a respective product, while no amplification was detected with the other three primers (Figure 2B). This suggested that an RNA molecule(s) in the "Elute" fraction was shorter than 1050 nts. To narrow down the size of the RNA molecule(s), we conducted an RT-PCR analysis using a series of six additional reverse primers (R660, R700, R750, R800, R850, R900) annealing at six different positions upstream of $1050 \mathrm{nt}$ position (Figure 2C). Among those, RT-PCR using only R660 and R700 yielded amplification of the corresponding products, which suggested that the template RNA molecule(s) were longer than 700 but shorter than $750 \mathrm{nts}$.

Subsequently, $5^{\prime}$ and $3^{\prime}$ RACE assays were employed to further elucidate the precise size of the RNA found in the association with the p33 protein. Each $5^{\prime}$ or $3^{\prime}$ RACE reaction produced a single fragment, which was then cloned and sequenced (Figure 2D; 100 and 10 clones for the $3^{\prime}$ and $5^{\prime}$ end determination, respectively). All clones generated from $5^{\prime}$ RACE used to determine the $5^{\prime}$-terminal sequence of the RNA molecule(s) bound to p33 shared the same sequence that corresponded to the very $5^{\prime}$ end of the CTV gRNA (data not shown). Remarkably, most reads obtained by sequencing of the clones produced from 3' RACE ended between 744 to 747 nt positions (Figure 2E; Supplementary Table S2) implying that the bound RNA could be a single species.

\subsection{CTV p33 Specifically Binds the Viral Non-Coding sgRNA LMT1}

Among the RNA molecules produced from the CTV genome during its replication is a sgRNA termed LMT1 $[11,13,14]$. As we showed previously, LMT1 is a viral long non-coding RNA that is involved in counter-acting host immune response [16]. The size of LMT1 for different isolates of CTV could slightly vary $[11,13,14]$. For the T36 isolate used in this study, an estimated size is about $750 \mathrm{nt}$, which is similar to that of the RNA molecule found to interact with the p33 protein. To confirm that p33 indeed binds the CTV LMT1, we performed RIP in which GFP:p33 was co-expressed with a mutant of CTV, which is unable to produce the LMT1 sgRNA (CTV-LMT1d; [16]), the LMT1-producing wild type CTV that is referred here as CTV-WT, or a transiently-expressed RNA that corresponds to LMT1 (pCASS-LMT1; [16]) in the N. benthamiana leaves (Figure 3A). Free GFP was used as a control for each treatment. Upon immunoprecipitation using GFP-Trap ${ }^{\circledR}$, the bound RNA was analyzed using RT-PCR with two sets of primers with the same forward primer (FW108). One set included a reverse primer annealing at the $660 \mathrm{nt}$ position (R660) for detection of the LMT1 molecule and the viral gRNA, while the other set included a reverse primer binding at the $900 \mathrm{nt}$ position (R900) that was designed to detect only gRNA. The shorter product (with R660) was amplified from the "Elute" RNA when GFP:p33 was co-expressed with either CTV-WT or transiently-expressed LMT1 (Figure 3B). No product was amplified from the same RNA template by the primer set with R900, confirming that the eluted RNA was shorter than 900 nts. On the contrary, RT-PCR using the "Elute" RNA from GFP:p33 co-expressed with the LMT1-deficient CTV-LMT1d resulted in no amplified 
product with either set, implying that no virus-produced RNA was bound to GFP:p33. The RNA eluted in the control treatment with free GFP yielded no amplification.

A
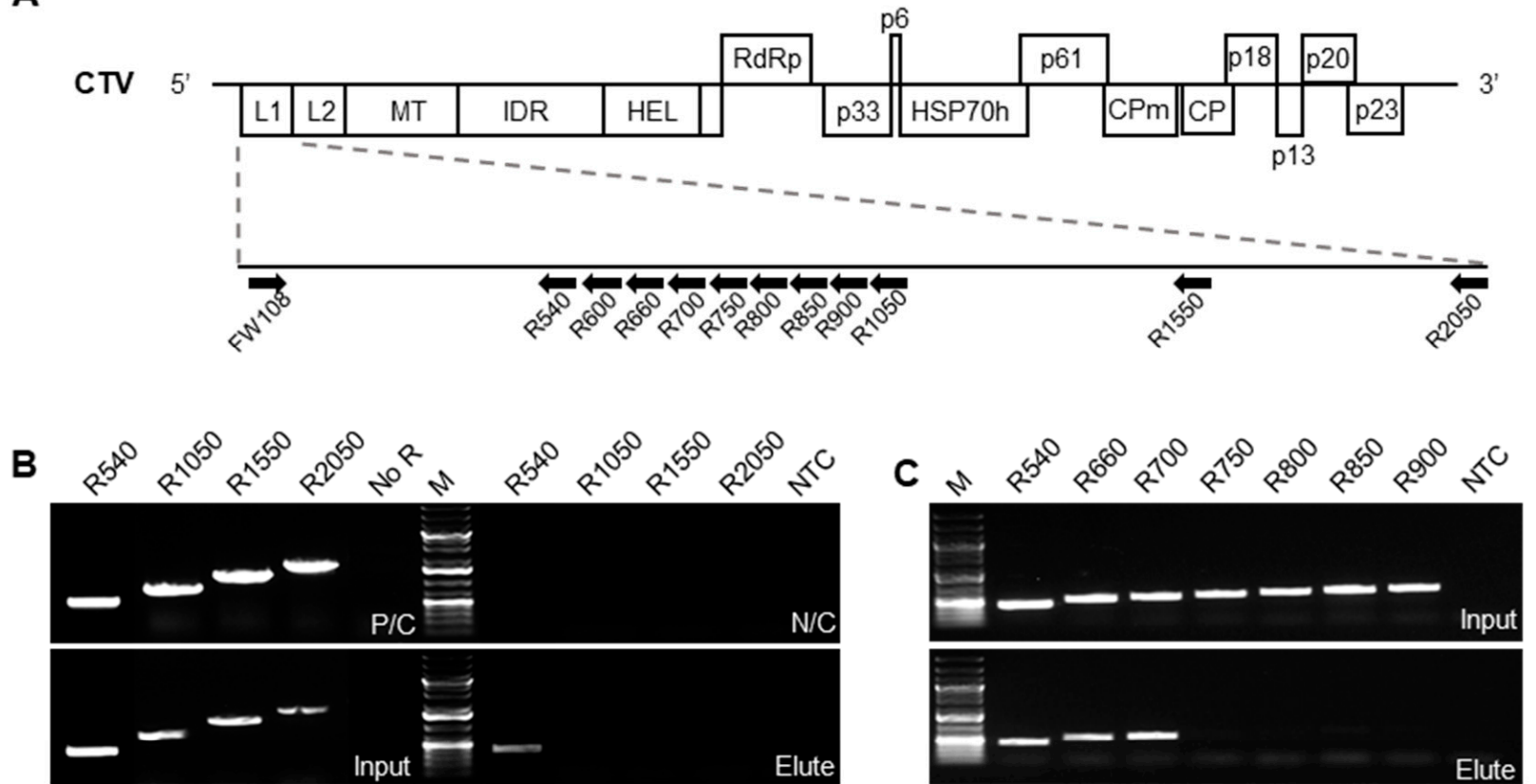

D

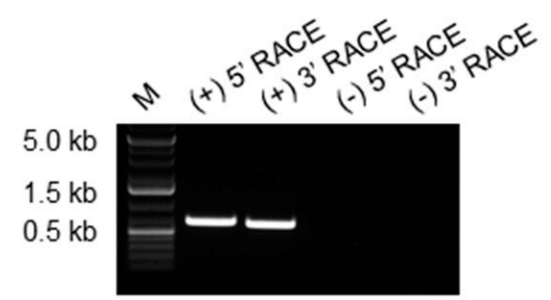

E

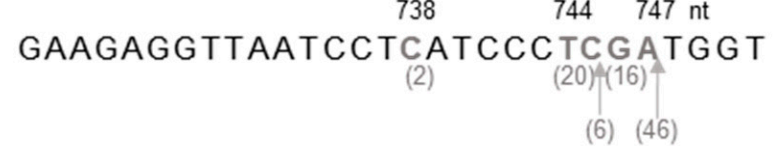

Figure 2. RNA molecule bound to the p33 protein is produced from the $5^{\prime}$ end of the CTV genome. (A) Schematic representation of the CTV genome and the positions of primers used in the RT-PCR analysis (shown in (B,C)). FW108 is a forward primer that corresponds to the nt position 108 in the CTV genome. Reverse primers (R) are named according to the nt positions they bind to the CTV genome (see Supplementary Table S1). (B) RT-PCR products of primer sets shown in (A) were analyzed by agarose gel electrophoresis. Molecular weight marker (M) has three bright bands indicating fragments of $0.5,1.5$, and $5.0 \mathrm{~kb}$ from the bottom to the top, respectively (as shown in (D)). P/C, RT-PCR using total RNA extract from CTV-infected tissue as a template. N/C, RT-PCR using water template. Input, see Figure 1B. Elute, total RNA extracted from the GFP-Trap beads at the completion of RIP assay (see Section 2). (C) RT-PCR products of primer sets shown in (A) were analyzed by agarose gel electrophoresis (continued from (B)). The image shows that the amplification no longer occurs with reverse primers annealing beyond $750 \mathrm{nt}$ position of the CTV genome. "Input" and "Elute" are described in (B). (D) 5' and 3' RACE for positive- and negative-stranded RNA using "Elute" RNA analyzed by agarose gel electrophoresis. Each amplified product shown in (+)5' RACE and $(+) 3^{\prime}$ RACE lanes was excised from the gel and cloned for sequencing. RACE reaction targeting negative-strands ((-)5' RACE and (-) $3^{\prime}$ RACE) produced no amplification. (E) The $3^{\prime}$ end sequence of $(+) 3^{\prime}$ RACE products determined by sequencing is shown. 46 out of 90 clean reads (out of 100 clones) ended at $747 \mathrm{nt}$ position of the CTV genome. 16, 6, 20, and 2 reads ended at 746, 745, 744, and 738 nt positions, respectively. NTC, no template control. 
A

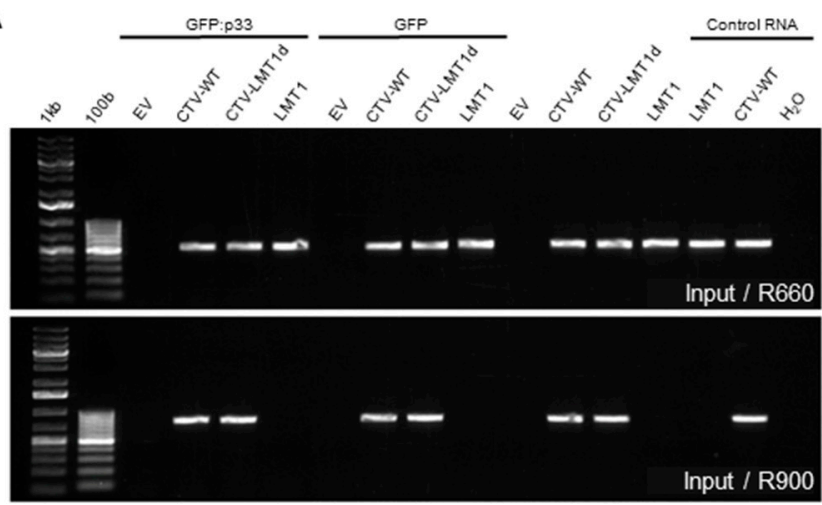

B

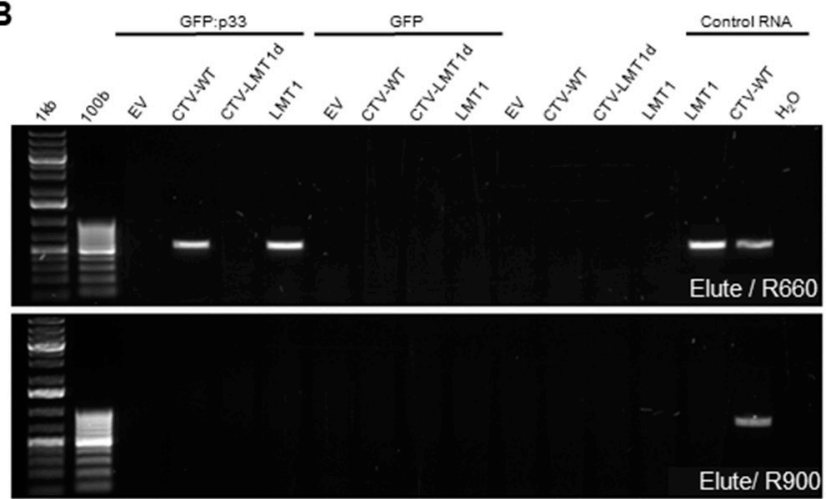

Figure 3. Non-coding sgRNA LMT1 produced from CTV binds to the p33 protein. The images show RT-PCR products analyzed by agarose gel electrophoresis. Each panel shows RT-PCR products using the total RNA extracted from the supernatant of the lysed homogenate of the leaf samples (Input, (A)) and the total RNA extracted from GFP-Trap beads at the completion of the RIP assay (Elute, (B)). The two sets of primers (R660 and R900) used to differentiate the shorter LMT1 RNA from the longer genomic RNA are described in Results. Control RNA samples are total RNA extracted from the leaves of $N$. benthamiana agroinfiltrated with a single construct as labeled. Two different molecular weight marker sets were used $(1 \mathrm{~kb}$ and $100 \mathrm{~b}) .1 \mathrm{~kb}$-marker was described in Figure 2. Another marker (100 b) has bands incremented by 100-bp size from $100 \mathrm{bp}$ to $1.0 \mathrm{~kb}$. EV, empty vector.

Based on the results described above, p33 showed high affinity to the sgRNA LMT1, yet did not appear to bind the viral gRNA, even though the sequence of LMT1 represents a part of the $5^{\prime}$-terminal region of gRNA. To validate the selective binding of p33 to LMT1, we compared binding properties between $\mathrm{p} 33$ and the CTV $\mathrm{p} 23$ protein. In this experiment, the RFP-tagged p33 and p23 proteins [30] were expressed in N. benthamiana plants along with the GFP-tagged wild-type CTV and CTV-LMT1d (Figure 4; CTV-GFP and CTV-LMT1d-GFP, respectively). The tagged proteins were immunoprecipitated using anti-RFP antibodylinked beads (RFP-Trap ${ }^{\circledR}$ ). As p23 was expected to bind other viral RNAs, including gRNA, in addition to LMT1, we used two sets of primers mentioned above to analyze protein-bound RNA. As we expected, both R660 and R900 yielded amplification of the respective fragments when the RNA eluted from the immunoprecipitated RFP:p23 was used as the template in the RT-PCR reactions, confirming that, besides LMT1, p23 protein is able to bind viral RNA containing regions downstream of that encoding LMT1 (Figure 4A). In contrast, RT-PCR using the "Elute" RNA in the treatment using RFP:p33 and CTV-GFP showed amplification of the shorter but not the longer fragment, which was similar to the result shown in Figures $1 \mathrm{~B}$ and 3B. No fragment was amplified from the post-RIP RNA obtained in the treatments using RFP:p33 alone or with CTV-LMT1d-GFP, indicating that no LMT1 molecule was produced, and p33 was unable to bind gRNA. We also included the wild-type CTV tagged with RFP (CTV-RFP) as a control to rule out a possibility of non-specific binding of CTV RNA to RFP. No amplification from the RNA eluted from the RFP-Trap ${ }^{\circledR}$ beads incubated with the extract from the leaves infiltrated with and CTV-RFP was detected, which confirmed the absence of a non-specific interaction between LMT1 and RFP. Expression of RFP:p23, RFP:p33, free RFP, and free GFP in the respective treatments was verified by Western blot analysis using RFP- or GFP- specific antibodies, respectively (Figure 4B).

\subsection{CTV p33 Binds to at Least Two Distinct Regions within LMT1}

To define a region(s) of LMT1 involved in binding to the $\mathrm{p} 33$ protein, we conducted EMSA assays using a purified p33 protein and in vitro-transcribed RNA molecules generated from a set of constructs in which truncated fragments of the LMT1 sequence were cloned under the T7 or SP6 promoter. To purify p33, we first cloned a full-length p33 ORF into the pGEX-4T-1 expression vector fused with an upstream GST tag for protein expression in E. coli. However, the yield of the GST-tagged p33 purified using Glutathione 
Sepharose ${ }^{\mathrm{TM}} 4 \mathrm{~B}$ beads was very low due to its insolubility. To circumvent this obstacle, a sequence encoding p33 lacking its C-terminal TMD was cloned into the expression vector, and GST:p33 $\triangle$ TMD was expressed and successfully purified using the procedures described above and in the Section 2 (Figure 5A). Next, we confirmed that the p33 protein with truncated TMD was still able to bind LMT1 in the RIP assay using the extracts from $N$. benthamiana leaves co-expressing GFP:p33 $\triangle$ TMD [26] with either the CTV-WT or CTV-LMT1d followed by RT-PCR with the R660 and R900 primer sets as described above (Supplementary Figure S3). Similar to what was observed with the full-length p33 protein, a primer set with R660 but not the one with R900 amplified a product corresponding to LMT1 when the "Elute" RNA in the treatment with GFP:p33 4 TMD and CTV-WT was used as the template for RT-PCR. No amplification occurred in the treatment with CTV-LMT1d. This result confirmed that truncation of TMD did not affect the ability of p33 protein in binding sgRNA LMT1, thus, supporting the employment of p33 TTMD in the EMSA assay.
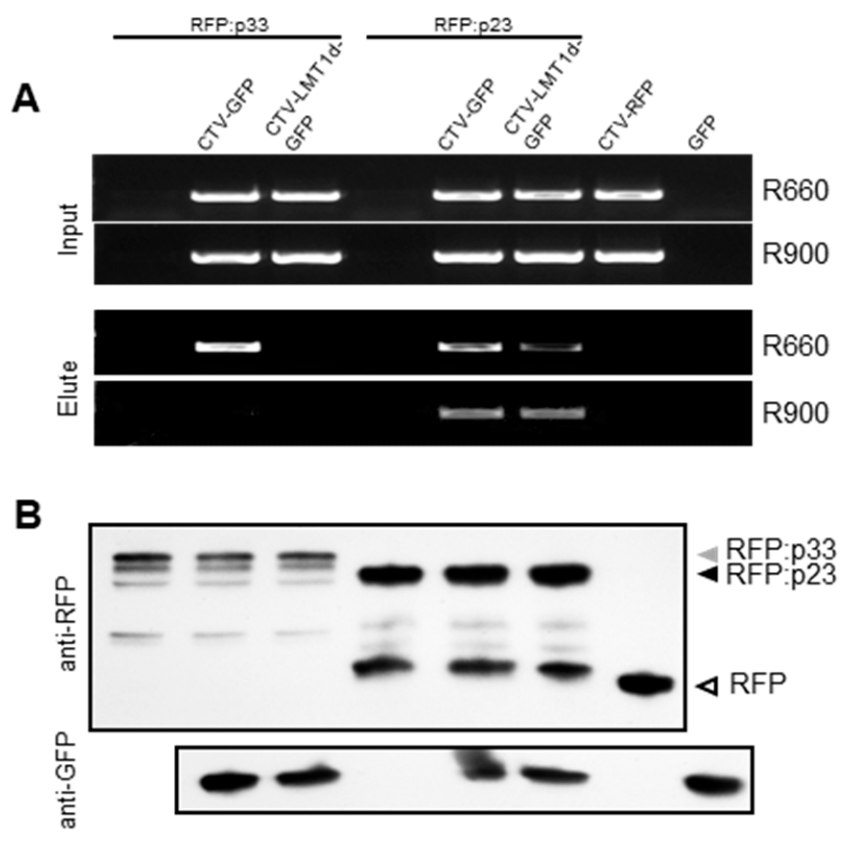

Figure 4. Comparison of the RNA binding properties of two CTV proteins-p33 and p23. The images show RT-PCR products and proteins in the corresponding RIP assay analyzed by agarose gel electrophoresis (A) or by immunoblot assay (B), respectively. (A) Each panel shows RT-PCR products generated using the total RNA extracted from the Input and Elute steps of the RIP assay (top and bottom, respectively). Two sets of primers, which included reverse primers R660 and R900, were used to differentiate the shorter LMT1 RNA from the longer genomic RNA. CTV-RFP (CTV-WT expressing free RFP) and GFP were used as controls to rule out the RFP-Trap precipitation of CTV RNA in the presence of non-tagged CTV proteins and free RFP or GFP, respectively. (B) Immunoblot analysis of the total protein extracts used as "Input" with an anti-GFP antibody to detect expression of free GFP produced by the CTV variants or the GFP control and an anti-RFP antibody to detect RFP-tagged proteins and free RFP produced by CTV-RFP.

To examine the interaction, increasing amounts of purified GST:p33 $\triangle$ TMD—as well as the GST protein alone-were incubated with in vitro-transcribed LMT1 RNA, separated on a non-denaturing gel, and transferred onto a nylon membrane. The membrane was hybridized with a DIG-labelled 5' CTV probe described above (see also Figure 1A) to detect LMT1. A shift in mobility was not observed until GST:p33 $\triangle$ TMD protein concentration was increased to $120 \mathrm{nM}$ (Figure 5B; full-length LMT1). p33 reached saturated binding with $1 \mu \mathrm{M}$ full-length LMT1 at a concentration of $210 \mathrm{nM}$. After fitting to the Hill equation, the affinity and the Hill coefficient were estimated as $121.6 \mathrm{nM}$ and 6.87, respectively (Figure 5C; Full length). This in vitro binding confirmed that p33 3 TMD binds LMT1 directly and does 
not need any host or virus factors as intermediates in binding. Furthermore, as the Hill coefficient reflects the cooperativity of protein and the target, the high Hill coefficient reading reflects positive cooperative binding (i.e., multiple binding sites on LMT1).

A

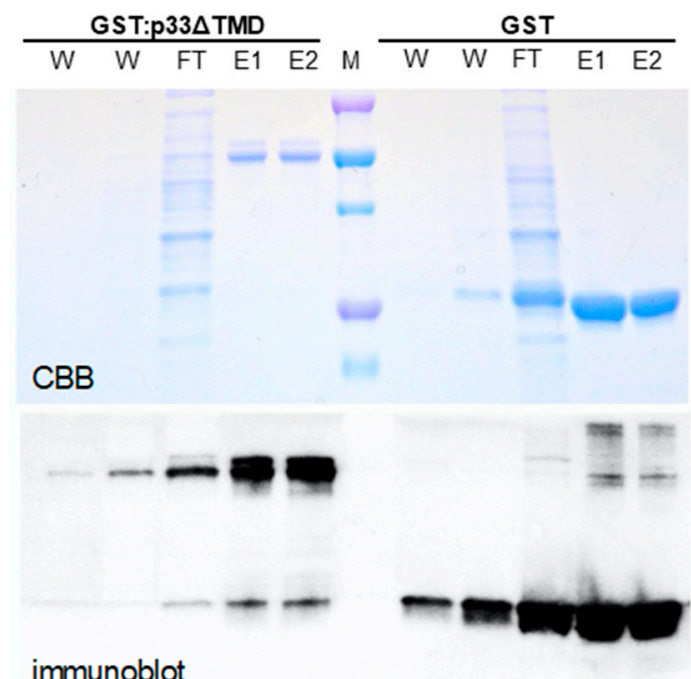

C

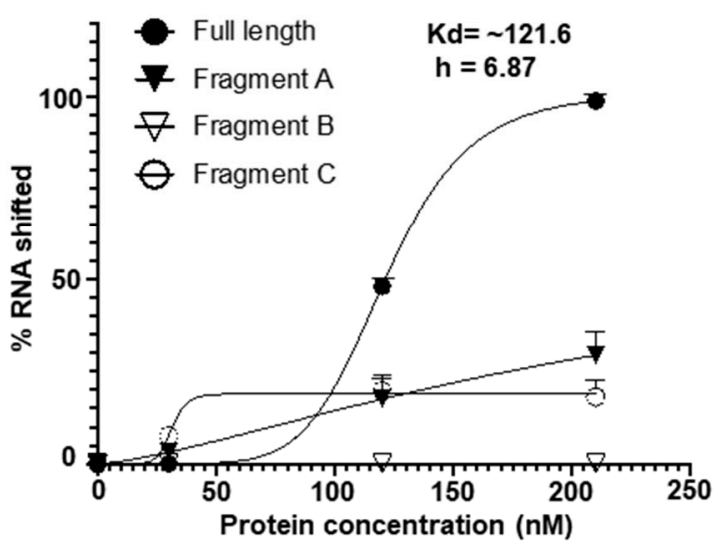

B

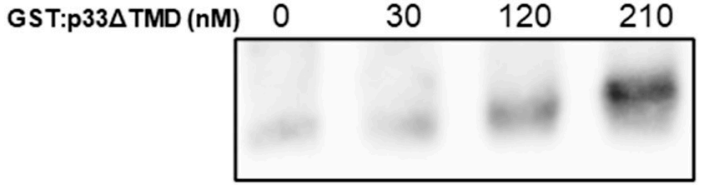

Full-length LMT1

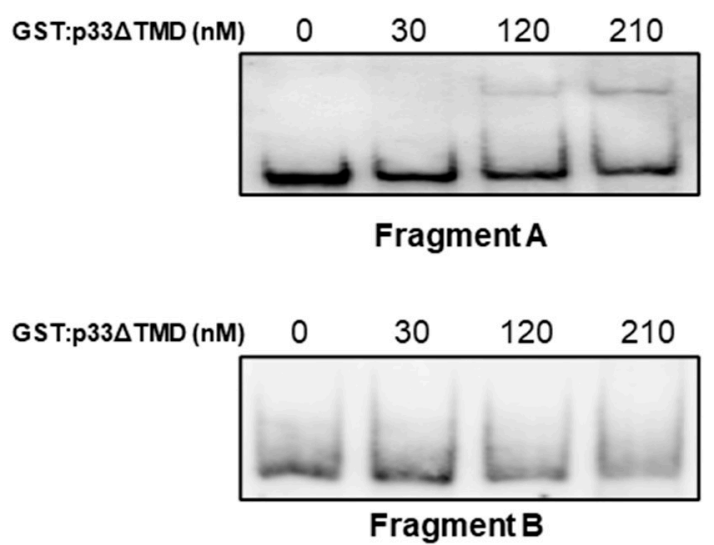

GST:p33ATMD (nM) $\quad 0 \quad 30 \quad 120 \quad 210$

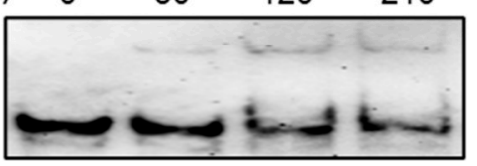

Fragment C

D

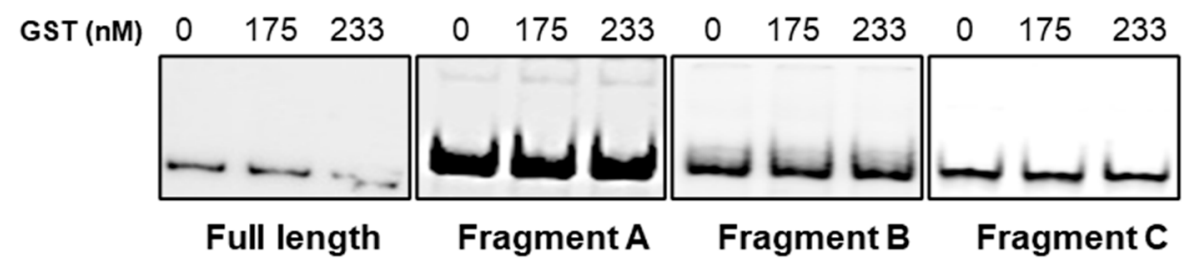

Figure 5. In vitro binding of purified p33 protein and LMT1 RNA or its truncated versions. (A) SDS-PAGE analysis of purified GST:p33 $\triangle$ TMD and GST proteins followed by Coomassie Brilliant Blue (CBB) staining. Proteins were verified using an anti-GST antibody after the transfer to the PVDF membrane (immunoblot). W, wash fraction; FT, flow-through fraction; E, elution fraction. (B) Kinetics of p33 and LMT1 binding was analyzed using a PAGE loaded with a series of varying amounts of purified GST:p33 binding kinetics between p33 and LMT-1 or LMT1-derived fragments were plotted to the Hill equation. The Kd and Hill coefficient (h) of p33 affinity to full-length LMT1 are listed. (D) GST alone did not bind with any of the tested RNA as shown by EMSA.

To identify the regions of LMT1 responsible for binding to p33, we first analyzed the LMT1 sequence using the mFOLD program, which predicted that the LMT1 secondary structure could be quite complex and have a number of clustered stem-loop structures [40] 
(Supplementary Figure S2). For further mapping of the binding region(s), we chose three fragments encompassing nt positions 201-400, 401-600, and 601-780 (fragments A, B, and $C$, respectively). We did not include the fragment encompassing nt positions 1-200 because this region alone cannot form a structure similar to the full-length RNA. As we determined earlier, the $3^{\prime}$ end of LMT1 maps to the nt position 747 (see Figure 2). Based on the mFOLD prediction showing that the structure of the $5^{\prime}$-terminal 747-nt fragment in the CTV genome representing LMT1 (Supplementary Figure S2) is highly similar to that of the $5^{\prime}$-terminal $780 \mathrm{nt}$ fragment, we chose a slightly longer length for the fragment $C$ to keep the length of all fragments used in the EMSA analysis comparable and, consequently, a longer length (780 nts) for a full-length RNA. Importantly, a prominent cluster of stem-loop structures in fragment $C$ located between nt positions 615 and 728 was preserved in both the 601-747 nt fragment (Supplementary Figure S2) and that encompassing nt positions 601-780 (data not shown). Sequences of fragments $\mathrm{A}, \mathrm{B}$, and $\mathrm{C}$ were cloned into a vector plasmid for in vitro transcription of RNA molecules to be used in EMSA analysis. A shift in mobility was detected with fragments A and C, but not with B (Figure 5B). Furthermore, it appeared that the $\mathrm{p} 33$ did not reach saturated binding of the $\mathrm{A}$ and $\mathrm{C}$ fragments as compared to that of the full-length LMT1 (Figure 5B,C). Therefore, it appears that cooperative binding accounts for the full binding affinity of the full-length transcript. We could not estimate the affinities to fragments A and C with confidence because we couldn't observe saturated shifting. Notably, GST alone did not bind to either full-length LMT1 or fragments (Figure 5D). These results suggested that there were at least two distinct p33 binding sites in LMT1.

\section{Discussion}

CTV is one of the most intricate viruses with a complex biology. Among the peculiar features of CTV is the production of a viral lncRNA LMT1. The $5^{\prime}$-terminal sgRNA LMT1 was discovered more than two decades ago, however, for years, its role in virus biology has remained unknown [41]. Recently, we showed that LMT1 is involved in counter-acting host defense response to CTV infection [16]. The $\mathrm{p} 33$ protein represents another remarkable trait of CTV. This unique protein is required for virus infection of a few selective citrus hosts yet it is dispensable for CTV infection of many other varieties of citrus [20,22]. With that, p33 could be regarded as the "champion" among other CTV proteins for various functions it performs in the virus infection cycle, which includes the involvement of p33 in viral superinfection exclusion, interaction with host immunity, and translocation in certain hosts (reviewed in [8]). Here, we show that p33 binds LMT1 with high affinity. We also demonstrate that at least two regions within LMT1 participate in the p33-LMT1 interaction. On the other hand, the p33 protein was not found to bind other CTV RNAs, suggesting that the observed interaction between p33 and LMT1 is highly specific.

Previously, many plant viral proteins were shown to bind RNA. A large number of these proteins are MPs, which interact with RNA in a sequence-non-specific manner, so they bind viral and non-viral RNA molecules with similar affinity (reviewed in [31]). Our earlier studies demonstrated that $\mathrm{p} 33$ shares multiple characteristics with MPs encoded in the genomes of other plant viruses $[26,28,30]$. In that respect, selective binding of the CTV p33 protein to a specific viral RNA species shown in this study is noteworthy and suggests that the RNA-binding property of p33 could be associated with a distinct function. In contrast to MPs, viral proteins that participate in virus replication by recruiting viral RNAs into replication complexes recognize and bind specific sequences within these RNA molecules. Examples of such proteins include Tomato bushy stunt virus (TBSV) replicase protein $\mathrm{p} 33$ that binds to an internal replication element of TBSV gRNA [42], RCNMV auxiliary replication protein p27 that recognizes a Y-shaped element in the $3^{\prime}$ untranslated region (UTR) of RNA2, which mediates its recruitment [43,44], and Brome mosaic virus (BMV) protein 1a that specifically interacts with the box B motifs in the BMV gRNAs $[45,46]$. For the TBSV p33 protein, it was shown that the specificity of RNA binding was dependent on the ability of p33 to form multimeric complexes [42]. This finding is in the agreement with a general observation that dimerization plays an important role in the specificity of RNA recognition 
as it provides multiple sites for RNA binding and strengthens the affinity of the protein to the RNA [47]. Interestingly, earlier, we demonstrated that CTV p33 also possesses a self-interaction ability [48], and this study showed a cooperative binding affinity of p33 to its RNA target.

The results of this work reporting binding of the CTV p33 protein, which is dispensable for virus replication, assembly, as well as cell-to-cell movement, to a viral lncRNA LMT1 stands out from known cases of plant viral protein-RNA interactions. LncRNAs were identified in a wide range of organisms, including prokaryotes, eukaryotes, and viruses, and represent RNA molecules with lengths more than $200 \mathrm{nts}$ and no apparent proteincoding capacity [49]. LncRNAs have been reported to be involved in numerous biological processes such as transcription regulation, microRNA suppression, cellular differentiation, development, and regulation of biotic and abiotic stresses [50]. Importantly, lncRNAs were often found interacting with RNA-binding proteins and acting as scaffolds for the formation of RNA-protein complexes or altering the activity and/or localization of the respective proteins [51,52]. Furthermore, lncRNAs play important roles in virus-host interactions. Many plant and animal lncRNAs are induced as either pro-viral or anti-viral factors upon viral infections [51,52]. Remarkably, several viruses have been shown to produce lncRNAs themselves that are often multifunctional. One example of such viral lncRNA is a subgenomic flavivirus RNA (sfRNA) derived from a $3^{\prime}$ UTR of a flavivirus genome. sfRNAs produced by different flaviviruses, including West Nile and dengue viruses, were found to suppress small-interfering RNA- and microRNA-induced RNA interference pathways by acting as competitive substrates for Dicer [53,54], bind and inhibit TRIM25, a protein vital for the activation of host antiviral response activation, or interact with host RNA-binding proteins that regulate interferon-stimulated genes [55,56]. Adding to the multifunctionality of sfRNAs, Zika virus sfRNA was reported to sequester an antiviral DEAD/H-box helicase ME31B, promoting virus replication and virion production to aid transmission by mosquitoes [57]. Another example is the polyadenylated nuclear (PAN) RNA produced by Kaposi's sarcoma-associated Virus (KSHV), a DNA herpesvirus. PAN RNA interacts with several host RNA-binding proteins to regulate viral and host gene expression [58-60], promote reactivation of KHSV by sequestering viral latency protein [61], and modulate immunity [62].

Plant virus lncRNAs have not received the same amount of attention as their animal virus counterparts, and our understanding of their functions remains limited. Beet necrotic yellow vein virus produces ncRNA3, a 500-nt long lncRNA with unknown function [63]. Another example is the 400-nt SRf1 produced by RCNMV. SRf1 originates from the $3^{\prime}$ UTR of RNA1 and suppresses cap-independent and cap-dependent translation as well as consequently represses the synthesis of the negative strand of RCNMV RNA by limiting the production of the replicase protein [64]. Unlike CTV LMT1, which is produced by the termination of RNA synthesis at a controller element on the negative strand complementary to gRNA [11,15], these two lncRNAs are products of degradation of gRNAs [63,64].

Although viral lncRNAs often bind the host proteins, fewer cases of the interactions between the former RNAs with proteins produced by the virus are known. One of them is the binding of KSHV PAN RNA to several KSHV proteins, which mediates regulation of the lytic reactivation and, overall, viral gene expression [65]. As for plant virus lncRNAs, to the best of our knowledge, binding of the CTV p33 protein to the CTV lncRNA LMT1 is the first report of a plant viral protein binding to a lncRNA produced by the same virus.

According to our recent study, the lack of LMT1 production by a CTV mutant reduced virus invasiveness and systemic movement in the CTV experimental host $N$. benthamiana and precluded citrus infection [16]. Furthermore, virus-driven or ectopic expression of LMT1 was found to modulate plant antiviral response by suppressing salicylic acid signaling and upregulating alternative oxidase, which limits Reactive oxygen species (ROS) production. Interestingly, the $\mathrm{p} 33$ protein is also involved in the virus interplay with host immunity. However, in contrast to LMT1, it triggers host defense against CTV infection, including the increase in the accumulation of ROS [25,27]. It is possible that interaction 
between these viral factors modulates host immune response to CTV infection and allows the virus to persist in the long-lived woody citrus host for the whole tree life, while reaching sufficient titers to be transmitted by the aphid vector to a new host.

Supplementary Materials: The following are available online at https://www.mdpi.com/article/ 10.3390/v13112129/s1, Figure S1: RNA binding motif of the p33 protein, Figure S2: Schematic representation of the LMT1 secondary structure prediction generated by mFOLD, Figure S3: LMT1 binding of the $\mathrm{p} 33$ protein lacking its transmembrane domain, Table S1: List of primers used in this study, Table S2: Sequence of clones produced from $3^{\prime}$ RACE. All authors have read and agreed to the published version of the manuscript.

Author Contributions: S.Y.F. conceived the study; S.-H.K., V.A., Y.W. and S.Y.F. designed the research; S.-H.K., V.A., L.K., S.D.D.M., Y.W. and S.Y.F. performed the research and analyzed the data; S.-H.K., V.A. and S.Y.F. wrote the manuscript with contributions. All authors have read and agreed to the published version of the manuscript.

Funding: This research was supported by the National Science Foundation (NSF) under Grant Number MCB-1615723 (to S. Y. Folimonova). The work in the Wang lab was supported by the NSF Grant Number MCB-1906060 (to Y. Wang). Any opinions, findings, and conclusions or recommendations expressed in this material are those of the author(s) and do not necessarily reflect the views of NSF.

Conflicts of Interest: The authors have no conflict of interest to declare.

\section{References}

1. Bar-Joseph, M.; Garnsey, S.M.; Gonsalves, D. The closteroviruses: A distinct group of elongated plant viruses. Adv. Virus Res. 1979, 25, 93-168. [CrossRef] [PubMed]

2. Dolja, V.V.; Karasev, A.V.; Koonin, E.V. Molecular biology and evolution of closteroviruses: Sophisticated build-up of large RNA genomes. Annu. Rev. Phytopathol. 1994, 32, 261-285. [CrossRef]

3. Dolja, V.V.; Kreuze, J.F.; Valkonen, J.P.T. Comparative and functional genomics of closteroviruses. Virus Res. 2006, 117, $38-51$. [CrossRef] [PubMed]

4. Agranovsky, A.A. Principles of molecular organization, expression, and evolution of closteroviruses: Over the barriers. Adv. Virus Res. 1996, 47, 119-158. [CrossRef]

5. Karasev, A.V. Genetic diversity and evolution of closteroviruses. Phytopathology 2000, 90, 293-324. [CrossRef] [PubMed]

6. Moreno, P.; Ambrós, S.; Albiach-Martí, M.R.; Guerri, J.; Peña, L. Citrus tristeza virus: A pathogen that changed the course of the citrus industry. Mol. Plant. Pathol. 2008, 9, 251-268. [CrossRef]

7. Dawson, W.O.; Bar-Joseph, M.; Garnsey, S.M.; Moreno, P. Citrus Tristeza Virus: Making an Ally from an Enemy. Annu. Rev. Phytopathol. 2015, 53, 137-155. [CrossRef] [PubMed]

8. Folimonova, S.Y. Citrus tristeza virus: A large RNA virus with complex biology turned into a valuable tool for crop protection. PLoS Pathog. 2020, 16, e1008416. [CrossRef] [PubMed]

9. Karasev, A.V.; Boyko, V.P.; Gowda, S.; Nikolaeva, O.V.; Hilf, M.E.; Koonin, E.V.; Niblett, C.L.; Cline, K.; Gumpf, D.J.; Lee, R.F.; et al. Complete sequence of the citrus tristeza virus RNA genome. Virology 1995, 208, 511-520. [CrossRef] [PubMed]

10. Gowda, S.; Satyanarayana, T.; Ayllón, M.A.; Albiach-Martí, M.R.; Mawassi, M.; Rabindran, S.; Garnsey, S.M.; Dawson, W.O. Characterization of the cis-acting elements controlling subgenomic mRNAs of citrus tristeza virus: Production of positive- and negative-stranded 3'-terminal and positive-stranded 5'-terminal RNAs. Virology 2001, 286, 134-151. [CrossRef] [PubMed]

11. Gowda, S.; Ayllon, M.A.; Satyanarayana, T.; Bar-Joseph, M.; Dawson, W.O. Transcription strategy in a Closterovirus: A novel $5^{\prime}$-proximal controller element of citrus tristeza virus produces $5^{\prime}$ - and $3^{\prime}$-terminal subgenomic RNAs and differs from $3^{\prime}$ open reading frame controller elements. J. Virol. 2003, 77, 340-352. [CrossRef] [PubMed]

12. Bar-Joseph, M.; Mawassi, M. The defective RNAs of Closteroviridae. Front. Microbiol. 2013, 4, 1-6. [CrossRef] [PubMed]

13. Che, X.; Piestun, D.; Mawassi, M.; Yang, G.; Satyanarayana, T.; Gowda, S.; Dawson, W.O.; Bar-Joseph, M. 5'-coterminal subgenomic RNAs in citrus tristeza virus-infected cells. Virology 2001, 283, 374-381. [CrossRef] [PubMed]

14. Gowda, S.; Tatineni, S.; Folimonova, S.Y.; Hilf, M.E.; Dawson, W.O. Accumulation of a 5' proximal subgenomic RNA of citrus tristeza virus is correlated with encapsidation by the minor coat protein. Virology 2009, 389, 122-131. [CrossRef]

15. Ayllón, M.A.; Gowda, S.; Satyanarayana, T.; Dawson, W.O. Cis-elements at the opposite ends of the Citrus tristeza virus genome differ in initiation and termination of subgenomic RNAs. Virology 2004, 322, 41-50. [CrossRef] [PubMed]

16. Kang, S.-H.; Sun, Y.-D.; Atallah, O.O.; Huguet-Tapia, J.C.; Noble, J.D.; Folimonova, S.Y. A Long Non-Coding RNA of Citrus tristeza virus: Role in the Virus Interplay with the Host Immunity. Viruses 2019, 11, 436. [CrossRef]

17. Pappu, H.R.; Karasev, A.V.; Anderson, E.J.; Pappu, S.S.; Hilf, M.E.; Febres, V.J.; Eckloff, R.M.; McCaffery, M.; Boyko, V.; Gowda, S. Nucleotide sequence and organization of eight $3^{\prime}$ open reading frames of the citrus tristeza closterovirus genome. Virology 1994, 199, 35-46. [CrossRef] [PubMed] 
18. Agranovsky, A.A. Closteroviruses: Molecular Biology, Evolution and Interactions with Cells. In Plant Viruses: Evolution and Management; Gaur, R.K., Petrov, N.M., Patil, B., Stoyanova, M.I., Eds.; Springer: Singapore, 2016; pp. 231-252. [CrossRef]

19. Satyanarayana, T.; Gowda, S.; Mawassi, M.; Albiach-Martí, M.R.; Ayllón, M.A.; Robertson, C.; Garnsey, S.M.; Dawson, W.O. Closterovirus encoded HSP70 homolog and p61 in addition to both coat proteins function in efficient virion assembly. Virology 2000, 278, 253-265. [CrossRef]

20. Tatineni, S.; Robertson, C.J.; Garnsey, S.M.; Bar-Joseph, M.; Gowda, S.; Dawson, W.O. Three genes of citrus tristeza virus are dispensable for infection and movement throughout some varieties of citrus trees. Virology 2008, 376, 297-307. [CrossRef] [PubMed]

21. Lu, R.; Folimonov, A.; Shintaku, M.; Li, W.-X.; Falk, B.W.; Dawson, W.O.; Ding, S.-W. Three distinct suppressors of RNA silencing encoded by a 20-kb viral RNA genome. Proc. Natl. Acad. Sci. USA 2004, 101, 15742-15747. [CrossRef]

22. Tatineni, S.; Robertson, C.J.; Garnsey, S.M.; Dawson, W.O. A plant virus evolved by acquiring multiple nonconserved genes to extend its host range. Proc. Natl. Acad. Sci. USA 2011, 108, 17366-17371. [CrossRef]

23. Folimonova, S.Y. Superinfection Exclusion Is an Active Virus-Controlled Function That Requires a Specific Viral Protein. J. Virol. 2012, 86, 5554-5561. [CrossRef] [PubMed]

24. Bergua, M.; Zwart, M.P.; El-Mohtar, C.; Shilts, T.; Elena, S.F.; Folimonova, S.Y. A Viral Protein Mediates Superinfection Exclusion at the Whole-Organism Level but Is Not Required for Exclusion at the Cellular Level. J. Virol. 2014, 88, 11327-11338. [CrossRef] [PubMed]

25. Sun, Y.; Folimonova, S.Y. The p33 protein of Citrus tristeza virus affects viral pathogenicity by modulating a host immune response. New Phytol. 2019, 221, 2039-2053. [CrossRef]

26. Kang, S.-H.; Bak, A.; Kim, O.-K.; Folimonova, S.Y. Membrane association of a nonconserved viral protein confers virus ability to extend its host range. Virology 2015, 482, 208-217. [CrossRef] [PubMed]

27. Sun, Y.; Zhang, L.; Folimonova, S.Y. Citrus miraculin-like protein hijacks a viral movement-related p33 protein and induces cellular oxidative stress in defence against Citrus tristeza virus. Plant. Biotechnol. J. 2021, 19, 977-991. [CrossRef] [PubMed]

28. Bak, A.; Folimonova, S.Y. The conundrum of a unique protein encoded by citrus tristeza virus that is dispensable for infection of most hosts yet shows characteristics of a viral movement protein. Virology 2015, 485, 86-95. [CrossRef]

29. Heinlein, M. Plasmodesmata: Channels for Viruses on the Move. In Plasmodesmata: Methods and Protocols; Heinlein, M., Ed.; Humana Press: New York, NY, USA, 2015; pp. 25-52. [CrossRef]

30. Dao, T.N.M.; Kang, S.-H.; Bak, A.; Folimonova, S.Y. A non-conserved p33 protein of Citrus tristeza virus interacts with multiple viral partners. Mol. Plant.-Microbe Interact. MPMI 2020, 33, 859-870. [CrossRef] [PubMed]

31. Hyodo, K.; Kaido, M.; Okuno, T. Host and viral RNA-binding proteins involved in membrane targeting, replication and intercellular movement of plant RNA virus genomes. Front. Plant. Sci. 2014, 5, 321. [CrossRef]

32. Giesman-Cookmeyer, D.; Lommel, S.A. Alanine scanning mutagenesis of a plant virus movement protein identifies three functional domains. Plant. Cell 1993, 5, 973-982. [CrossRef]

33. Herranz, M.C.; Sanchez-Navarro, J.-A.; Saurí, A.; Mingarro, I.; Pallás, V. Mutational analysis of the RNA-binding domain of the Prunus necrotic ringspot virus (PNRSV) movement protein reveals its requirement for cell-to-cell movement. Virology 2005, 339, 31-41. [CrossRef]

34. Kalinina, N.O.; Rakitina, D.A.; Yelina, N.E.; Zamayatnin, A.A., Jr.; Stroganova, T.A.; Klinov, D.V.; Prokhorov, V.V.; Ustinova, S.V.; Chernov, B.K.; Schiemann, J.; et al. RNA-binding properties of the $63 \mathrm{kDa}$ protein encoded by the triple gene block of poa semilatent hodeivirus. J. Gen. Virol. 2001, 82, 2569-2578. [CrossRef]

35. Atallah, O.O.; Kang, S.-H.; El-Mohtar, C.A.; Shilts, T.; Bergua, M.; Folimonova, S.Y. A 5'-proximal region of the Citrus tristeza virus genome encoding two leader proteases is involved in virus superinfection exclusion. Virology 2016, 489, 108-115. [CrossRef] [PubMed]

36. Rajendran, K.S.; Nagy, P.D. Characterization of the RNA-binding domains in the replicase proteins of tomato bushy stunt virus. J. Virol. 2003, 77, 9244-9258. [CrossRef]

37. Satyanarayana, T.; Gowda, S.; Boyko, V.P.; Albiach-Marti, M.R.; Mawassi, M.; Navas-Castillo, J.; Karasev, A.V.; Dolja, V.; Hilf, M.E.; Lewandowski, D.J.; et al. An engineered closterovirus RNA replicon and analysis of heterologous terminal sequences for replication. Proc. Natl. Acad. Sci. USA 1999, 96, 7433-7438. [CrossRef] [PubMed]

38. Casu, F.; Duggan, B.M.; Hennig, M. The arginine-rich RNA-binding motif of HIV-1 Rev is intrinsically disordered and folds upon RRE binding. Biophys. J. 2013, 105, 1004-1017. [CrossRef]

39. López, C.; Navas-Castillo, J.; Gowda, S.; Moreno, P.; Flores, R. The 23 kDa protein coded by the $3^{\prime}$-terminal gene of Citrus tristeza virus is an RNA-binding protein. Virology 2000, 269, 462-470. [CrossRef] [PubMed]

40. Zuker, M. Mfold web server for nucleic acid folding and hybridization prediction. Nucleic Acids Res. 2003, 31, $3406-3415$. [CrossRef] [PubMed]

41. Mawassi, M.; Karasev, A.V.; Mietkiewska, E.; Gafny, R.; Lee, R.F.; Dawson, W.O.; Bar-Joseph, M. Defective RNA molecules associated with citrus tristeza virus. Virology 1995, 208, 383-387. [CrossRef]

42. Pogany, J.; White, K.A.; Nagy, P.D. Specific binding of Tombusvirus replication protein p33 to an internal replication element in the viral RNA is essential for replication. J. Virol. 2005, 79, 4859-4869. [CrossRef]

43. Iwakawa, H.-O.; Mine, A.; Hyodo, K.; An, M.; Kaido, M.; Mise, K.; Okuno, T. Template recognition mechanism by replicase proteins differ between bipartite positive-strand genomic RNAs of a plant virus. J. Virol. 2011, 85, 497-509. [CrossRef] 
44. Hyodo, K.; Mine, A.; Iwakawa, H.-O.; Kaido, M.; Mise, K.; Okuno, T. Identification of amino acids in auxiliary replicase protein p27 critical for its RNA-binding activity and the assembly of the replicase complex in Red clover necrotic mosaic virus. Virology 2011, 413, 300-309. [CrossRef]

45. Sullivan, M.; Ahlquist, P. A brome mosaic virus intergenic RNA3 replication signal functions with viral replication protein 1a to dramatically stabilize RNA in vivo. J. Virol. 1999, 73, 2622-2632. [CrossRef]

46. Chen, J.; Noueiry, A.; Ahlquist, P. Brome mosaic virus protein 1a recruits viral RNA2 to RNA replication through a $5^{\prime}$ proximal RNA2 signal. J. Virol. 2001, 75, 3207-3219. [CrossRef] [PubMed]

47. Ban, T.; Zhu, J.K.; Melcher, K.; Xu, H.E. Structural mechanisms of RNA recognition: Sequence-specific and non-specific RNAbinding proteins and the Cas9-RNA-DNA complex. Cell Mol. Life Sci. 2015, 72, 1045-1058. [CrossRef] [PubMed]

48. Kang, S.H.; Dao, T.N.M.; Kim, O.K.; Folimonova, S.Y. Self-interaction of Citrus tristeza virus p33 protein via N-terminal helix. Virus Res. 2017, 233, 29-34. [CrossRef] [PubMed]

49. Ma, L.; Bajic, V.B.; Zhang, Z. On the classification of long non-coding RNAs. RNA Biol. 2013, 10, 925-933. [CrossRef] [PubMed]

50. Kumar, K.; Chakraborty, S. Roles of long non-coding RNAs in plant virus interactions. J. Plant. Biochem. Biotechnol. 2021. [CrossRef]

51. Prasad, A.; Prasad, M. Host-virus interactions mediated by long non-coding RNAs. Virus Res. 2021, 298, 198402. [CrossRef]

52. Wang, P. The Opening of Pandora's Box: An Emerging Role of Long Noncoding RNA in Viral Infections. Front. Immunol. 2019, 9, 3138. [CrossRef]

53. Schnettler, E.; Sterken, M.G.; Leung, J.Y.; Metz, S.W.; Geertsema, C.; Goldbach, R.W.; Vlak, J.M.; Kohl, A.; Khromykh, A.A.; Pijlman, G.P. Noncoding flavivirus RNA displays RNA interference suppressor activity in insect and Mammalian cells. J. Virol. 2012, 86, 13486-13500. [CrossRef]

54. Schnettler, E.; Tykalová, H.; Watson, M.; Sharma, M.; Sterken, M.G.; Obbard, D.J.; Lewis, S.H.; McFarlane, M.; Bell-Sakyi, L.; Barry, G.; et al. Induction and suppression of tick cell antiviral RNAi responses by tick-borne flaviviruses. Nucleic Acids Res. 2014, 42, 9436-9446. [CrossRef] [PubMed]

55. Bidet, K.; Dadlani, D.; Garcia-Blanco, M.A. G3BP1, G3BP2 and CAPRIN1 Are Required for Translation of Interferon Stimulated mRNAs and Are Targeted by a Dengue Virus Non-coding RNA. PLoS Pathog. 2014, 10, e1004242. [CrossRef] [PubMed]

56. Manokaran, G.; Finol, E.; Wang, C.; Gunaratne, J.; Bahl, J.; Ong, E.Z.; Tan, H.C.; Sessions, O.M.; Ward, A.M.; Gubler, D.J.; et al. Dengue subgenomic RNA binds TRIM25 to inhibit interferon expression for epidemiological fitness. Science 2015, 350, $217-221$. [CrossRef] [PubMed]

57. Göertz, G.P.; van Bree, J.; Hiralal, A.; Fernhout, B.M.; Steffens, C.; Boeren, S.; Visser, T.M.; Vogels, C.; Abbo, S.R.; Fros, J.J.; et al. Subgenomic flavivirus RNA binds the mosquito DEAD/H-box helicase ME31B and determines Zika virus transmission by Aedes aegypti. Proc. Natl. Acad. Sci. USA 2019, 116, 19136-19144. [CrossRef] [PubMed]

58. Borah, S.; Darricarrere, N.; Darnell, A.; Myoung, J.; Steitz, J.A. A viral nuclear noncoding RNA binds re-localized poly(A) binding protein and is required for late KSHV gene expression. PLoS Pathog. 2011, 7, e1002300. [CrossRef]

59. Rossetto, C.C.; Pari, G. KSHV PAN RNA associates with demethylases UTX and JMJD3 to activate lytic replication through a physical interaction with the virus genome. PLoS Pathog. 2012, 8, e1002680. [CrossRef]

60. Rossetto, C.C.; Tarrant-Elorza, M.; Verma, S.; Purushothaman, P.; Pari, G.S. Regulation of viral and cellular gene expression by Kaposi's sarcoma-associated herpesvirus polyadenylated nuclear RNA. J. Virol. 2013, 87, 5540-5553. [CrossRef]

61. Campbell, M.; Kim, K.Y.; Chang, P.C.; Huerta, S.; Shevchenko, B.; Wang, D.H.; Izumiya, C.; Kung, H.J.; Izumiya, Y. A lytic viral long noncoding RNA modulates the function of a latent protein. J. Virol. 2014, 88, 1843-1848. [CrossRef]

62. Rossetto, C.C.; Pari, G.S. Kaposi's sarcoma-associated herpesvirus noncoding polyadenylated nuclear RNA interacts with virus- and host cell-encoded proteins and suppresses expression of genes involved in immune modulation. J. Virol. 2011, 85, 13290-13297. [CrossRef]

63. Peltier, C.; Klein, E.; Hleibieh, K.; D'Alonzo, M.; Hammann, P.; Bouzoubaa, S.; Ratti, C.; Gilmer, D. Beet necrotic yellow vein virus subgenomic RNA3 is a cleavage product leading to stable non-coding RNA required for long-distance movement. J. Gen. Virol. 2012, 93, 1093-1102. [CrossRef] [PubMed]

64. Iwakawa, H.-O.; Mizumoto, H.; Nagano, H.; Imoto, Y.; Takigawa, K.; Sarawaneeyaruk, S.; Kaido, M.; Mise, K.; Okuno, T. A viral noncoding RNA generated by Cis-element-mediated protection against $5^{\prime} \rightarrow 3^{\prime}$ RNA decay represses both cap-independent and cap-dependent translation. J. Virol. 2008, 82, 10162-10174. [CrossRef] [PubMed]

65. Rossetto, C.C.; Pari, G.S. PAN's Labyrinth: Molecular Biology of Kaposi's Sarcoma-Associated Herpesvirus (KSHV) PAN RNA, a Multifunctional Long Noncoding RNA. Viruses 2014, 6, 4212-4226. [CrossRef] [PubMed] 